RESEARCH ARTICLES

\title{
FEEDING SITE USAGE BY GRIFFON VULTURES (GYPS FULVUS) IN BULGARIA REVEALED BY CAMERA TRAPS
}

\author{
Dimitar I. Nenov ${ }^{1, *}$, Diana P. Zlatanova ${ }^{1}$, Emilian H. Stoynov ${ }^{2, * *}$, \\ Hristo V. Peshev ${ }^{2}$, Atanas P. Grozdanov ${ }^{1}$ \\ ${ }^{1}$ Sofia University «St. Kliment Ohridski», Bulgaria \\ *e-mail:dinenov@uni-sofia.bg \\ ${ }^{2}$ Fund for Wild Flora and Fauna \\ **e-mail:pirin@fwff.org
}

Received: 31.01.2018

\begin{abstract}
A group of griffon vultures in Kresna Gorge was studied for its visit on the feeding station next to Rakitna Village after being reintroduced in the area. A camera trap method was used for a better understanding of the breeding behaviour of the griffon vulture, including the intra- and inter-species relations. A statistically significant difference was found between the independent feeding events during the pre-incubation and incubation periods of vultures. The duration of those events also differs, the ones in the second period being longer. Furthermore, a statistically significant difference was observed between the number of vultures per photo for the two sample periods, as a result of a different number of unmarked wild birds and different activity patterns of the nesting pairs. In spite of the fact that the terrestrial predators are also active during the night, their daytime presence leads to a high enough overlap between the two ecological groups, showing that the carnivores are a disturbance factor for the scavengers. The raven is the most abundant species at the feeding site and thus is a food competitor to the griffon vulture. The two species have adapted their behaviour to use the feeding station more successfully during the different biological periods. A significant decrease in the activity overlap between the individuals of the successfully nesting pairs was observed on the feeding station after the beginning of the incubation period. On the other hand, the activity overlap of the unsuccessfully nesting pairs increased in the second sample period. Camera traps can be used in further studies of the mating ecology for individual breeding pairs, when a direct observation on the nest is hard or impossible. This can be a cheap alternative of the time-consuming field observations.
\end{abstract}

Key words: breeding and non-breeding pairs, camera trap, griffon vulture

\section{Introduction}

The four European vulture species: Griffon vulture (Gyps fulvus Hablizl, 1783), Cinereous vulture (Aegypius monachus Linnaeus, 1766), Egyptian vulture (Neophron percnopterus Linnaeus, 1758), and Bearded vulture (Gypaetus barbatus Linnaeus, 1758), are currently under severe threat by humans (Margalida \& Colomer, 2012). Some of the biggest conservation threats include loss of habitat and food resources, which can lead to the change of the scavengers' feeding behaviour (Zuberogoitia et al., 2010; Margalida et al., 2011). This calls for the need of creating vulture feeding sites, when the natural food resources are low (Margalida et al., 2017).

The feeding stations (also called feeding sites or vulture restaurants), are specialised areas with restricted human access where carrion is being deposited. The presence of these feeding sites is one of the most important anthropogenic factors, which have impact on the abundance of the scavengers, which use those (Kane et al., 2016). Griffon vulture colonies successfully use feeding stations in the proximity up to $9 \mathrm{~km}$ from the breeding site, without significant pressure by other colonies (Xirouchakis \& Andreou, 2009). The birds spend most of the day searching for food, and the presence of a feeding site lowers the time needed for that.

The observations on the vulture restaurants can provide valuable information about the dynamics of the vulture population. On the feeding stations, the age structure of the group can be identified by comparing the molting patterns of the individuals. The number of the vultures visiting the station can be used as an index of its abundance. The ratio between the marked and unmarked birds can provide information about the population size (Wolter \& Whittington-Jones, 2011).

Kresna Gorge in Bulgaria is a very important hotspot for bird species of conservation significance (Stoynov et al., 2014). Although the Griffon vulture was categorised as Least Concern (LC) by the 
IUCN (BirdLife International, 2017), it disappeared from Kresna Gorge during the $20^{\text {th }}$ century. In 2009 the Fund for Wild Flora and Fauna (FWFF) started a reintroduction program for the species in this area which persisted with success till the end of 2016 (Stoynov \& Peshev, 2012, 2013, 2014, 2015; Peshev et al., 2016, 2017). The first breeding attempts of the Griffon vulture dated back to 2010 (Stoynov \& Grozdanov, 2011), but the first successfully raised fledglings left the nests only in 2016.

At the beginning of 2017 a significant part of the new colony was eradicated by deposited poisoned bait near one of the villages in the region. The use of poison is one of the main reasons of mass vulture deaths in Europe, as well as the usage of antibiotics for the livestock which further was transferred to the vultures with the dead animals (Green et al., 2004; Margalida et al., 2010; Green et al., 2016). From the conservation point of view keeping the vultures away from the poison baits by providing a ready to use food source had proven to be the best practice. All these circumstances call for the need to gather more information about the frequency with which the vultures are using the safe feeding stations, their feeding behaviour and habits of the other scavengers to visit these stations as a disturbance factor. The best approach for studying these aspects is the noninvasive method of camera trapping, which allows for collecting data in a non-intrusive way, by removing the presence of a human factor near the station. Nowadays the camera traps are mainly used for medium and large mammal observations (O'Connell et al., 2011). The camera trap method is widely used in mammal research in Bulgaria, for example, the first hard evidence of the Eurasian lynx (Lynx lynx L.) after more than 60 years of extinction in Bulgaria was obtained through such a study (Zlatanova et al., 2009). There are many other mammal studies in Bulgaria that also employ camera trapping; this method is often used in the practice of state or private game units too.

There is no developed camera trap study design or structured analyses for vultures, especially for feeding sites, yet. Even more, there are only a few studies of the avian fauna ever made with automated cameras (Demo et al., 2013; Samson \& Ramakrishnan, 2017). This is why the current research is important, aiming to set the grounds for evaluation of the vulture restaurants usage by griffon vultures, estimation of their feeding periodicity, the intraspecies dynamics and the intra- and inter-species relations.

\section{Material and Methods \\ Study area and research objects}

The feeding station is located next to Rakitna Village (Simitli Municipality/Blagoevgrad Province, Bulgaria), above the Kresna Gorge (Fig. 1). The vulture restaurant is inside two nature protected areas by the Natura 2000 network: Kresna (Special Protection Area for Birds BG0002003) and Kresna-Ilindenci (Site of Community Importance BG0000366). In close proximity are located the rock massifs, used by the colony as roosting and nesting sites.

The feeding station is an enclosure containing the adaptation aviary and surrounded by an electric fence. The carcasses deposit station is located right next to the aviary, which intends to increase the numbers of the wild and released vultures to the station. Carcass remains (bones, skin, horns, etc.) are not removed from the station after cleared from meat to attract additionally the scavengers. A new carcass is deposited at least four times per week. In 2016, a total of 50 tons of carcasses were left there.

One camera trap has been positioned on the metal frame of the aviary (Fig. 1), and the observation field contained the deposited food. The camera trap was placed before the vultures were provided with an access to the station. There is no obvious and intended behaviour from the vultures to the camera trap which ensured us that the presence of the camera trap is not having any influence on the vulture behaviour as they perceive it as a part of the surrounding area. A small area outside the fence was also included in the viewing field of the camera trap. The device was positioned around 1.5 meters above the ground, and approximately 6 meters from the deposited carcasses, under an angle of about $10^{\circ}$, as suggested by Wilson (2015).

The camera trap model was Bushnell 119327. It is equipped with a 5 megapixels sensor and produces JPEG pictures with size of 3264 by 2832 pixels. The device was active 24 hours per day and uses both a movement sensor and an infrared sensor. For night photos, it uses an infrared flashlight. It uses eight AA batteries, and was set to make only photos with 15 seconds interval between them. The photos are downloaded on a hard drive whenever carcasses were being deposited.

The object of the current research is the group of griffon vultures in Kresna Gorge that visit the feeding station next to Rakitna Village after being reintroduced in the area by the Fund for Wild Flora and Fauna (FWFF). 


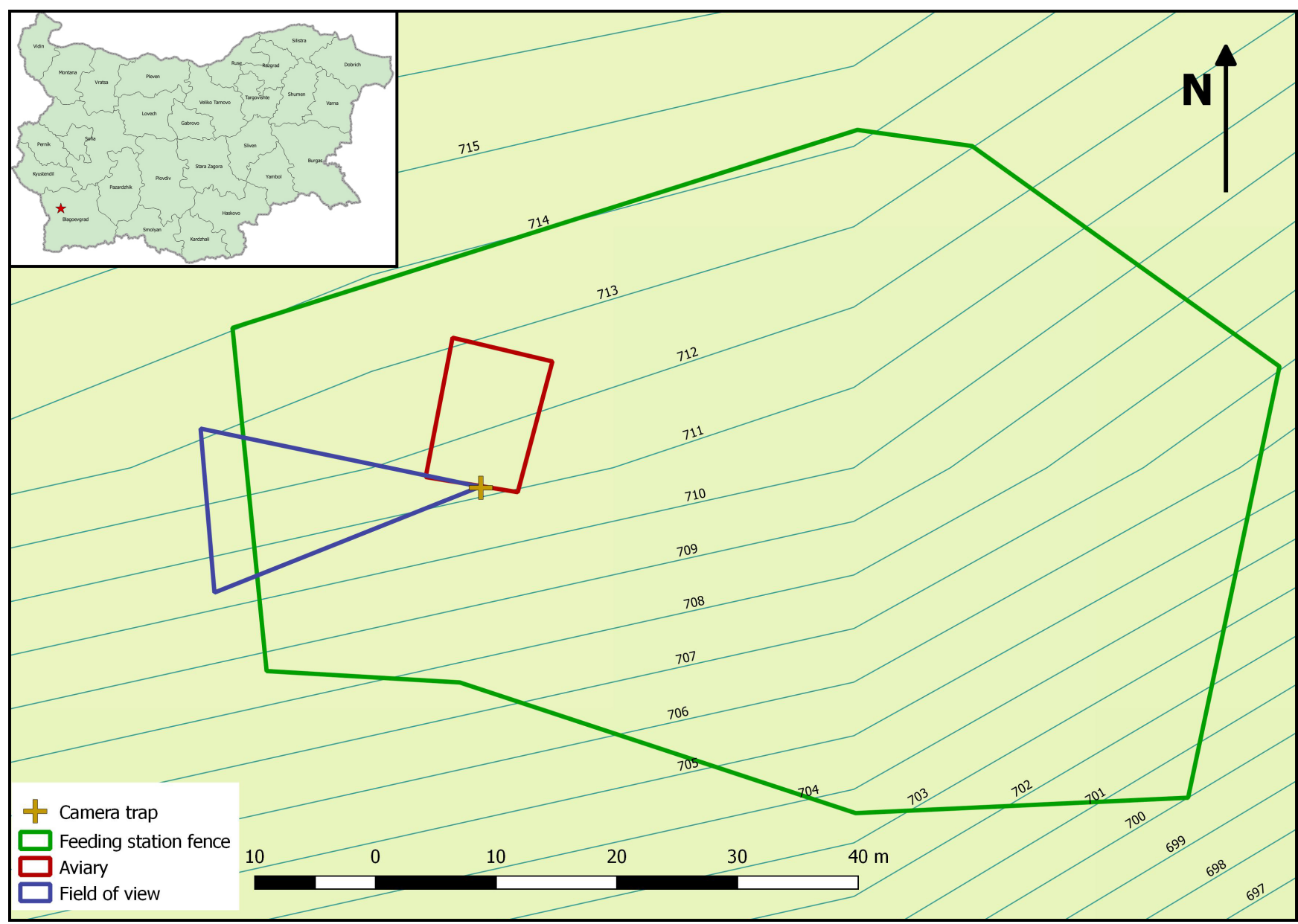

Fig. 1. Location of the feeding station (with star on the overview map) and the setting of the feeding site and the camera trap used.

The productivity of the colony (the number of successfully raised fledglings per number of pairs) is $25 \%$, while the breeding success (the number of the successfully raised fledglings per laid eggs) is $100 \%$. The ratio between the productivity and the breeding success is $25 \%$, which is significantly lower compared to another stable European colonies (natural and reintroduced) $-65 \%$ for Crete (Xirouchakis \& Mylonas, 2005) and 79.6\% for Central France (Sarrazin et al., 1994).

The current griffon vulture reintroduction and reinforcement projects include transportation of birds from Western Europe, which are placed in an adaptation aviary. They are marked with wing marks and rings, allowing them to be individually recognised and after an adaptation period they are released in the wild. In 2016, eight vulture breeding pairs were registered in the wild in Kresna Gorge (Table 1). For six of the pairs both individuals are marked, while for two of them the females are unmarked wild birds. Two of the pairs nested, laid an egg, and raised a fledgling successfully. One of the chicks was marked in the nest by the FWFF (Peshev et al., 2017).

Table 1. Breeding pairs of marked (and wild) griffon vultures, nest occupation dates, first recorded copulation dates, egg laying dates and egg hatching dates

\begin{tabular}{|c|c|c|c|c|c|}
\hline Male & Female & Nest occupation & First copulation & Egg laying & Egg hatching \\
\hline B35-P & B61 & 12.2015 & unknown & 29.01 .2016 & 27.03 .2016 \\
\hline M60-X & B39-H & 01.2016 & 22.11 .2015 & 05.02 .2016 & 03.04 .2016 \\
\hline B17-M & B95-5 & 01.2016 & 28.01 .2016 & - & - \\
\hline K44 & K47 & 01.2016 & 31.01 .2016 & - & - \\
\hline F96-6 & B00-A & 01.2016 & 16.02 .2016 & - & - \\
\hline B34-O & G92 & 01.2016 & 16.02 .2016 & - & - \\
\hline B19-C & wild & - & - & - & - \\
\hline K & wild & - & - & - & - \\
\hline
\end{tabular}


The analysed data is from two pre-chosen periods - pre-incubation and incubation. The pre-incubation period is from 01.01.2016 till 18.01.2016 ( $\mathrm{n}=18$ days) and includes the completion of the nests, just before the first egg in the colony was laid by the B35-P(đ) - B61( 9$)$ pair. The incubation period is from 29.01.2017 till 17.03.2017 $(\mathrm{n}=49$ days $)$ and includes the incubation of the two eggs in the colony. Between the two periods a 10-day gap in the data was left for ensuring that they will not be any overlap (to avoid a temporal error in the identification of the first egg laying date).

\section{Analyses}

The analysed data pool contains photos from the 67 camera trap days, i.e. 18 from the pre-incubation period and 49 from the incubation period. A total of 8042 pictures were analysed (2872 for the pre-incubation and 5170 for the incubation period), grouped in 966 independent events (registrations of the bird visiting the site separated with at least 30 minutes gap from the next visit).

The JPEG pictures with EXIF files were systematised and analysed via a specialised Microsoft Access database - Camera Base 1.7 (Tobler, 2015), adapted, developed and translated in Bulgarian (Zlatanova, 2014: personal communication). The program was further adapted to cut the processing of the data with a new field for the number of the ravens (Corvus corax Linnaeus, 1758). Additionally, a special spreadsheet table was created, containing information about the marked vultures.

Since the pre-incubation and the incubation period are different in length, for the aim of comparison, the data were standardised as a detection rate (DR) index. It represents the number of the registered independent events per one camera trap day:

$$
D R=\frac{n_{i}}{T},
$$

where $D R$ - detection rate index; $n_{i}$ - number of the independent events; $T$ - length of the period in days;

The map was created with QGIS (2.18.10) (QGIS Development Team, 2017). The statistical analyses were performed with SigmaStat 3.5 (Systat Software, 2007), SigmaPlot 11.0 (Systat Software, 2008) and R 3.4.0 (R Core Team, 2017).

The numbers of the independent events, the numbers of the feeding events and the numbers of the independent events with marked vultures were tested for a statistically significant difference for the two periods using the $\chi^{2}$ (chi-square) test. The differences between groups in the pre-incubation and incubation periods were tested with the MannWhitney U-test.

The analyses on the activity and the overlap of the different visits at the feeding station was done via the overlap package (Meredith \& Ridout, 2017) for R. Overlap coefficients were calculated with nonparametric estimators $\Delta_{1}$ and $\Delta_{4}$ (Schmid \& Schmidt, 2006; Ridout \& Linkie, 2009). $\Delta_{1}$ was used when the lesser of the two samples was with $\mathrm{n}<50$, and $\Delta_{4}$ when it was with $\mathrm{n}>75$. The coefficient of overlap varies between 0 and 1 , where a 0 means that the activity patterns of the two species/ individuals do not overlap at all, and a 1 is when the overlap is total.

For the analyses of the overlap two approaches were possible. Firstly, the hour of every photo is considered only once, despite the number of individuals on the picture, because most of the times when more than one individual is observed, it is a constant group of individuals during that period. Secondly, the hour of each photo is considered as many times, as the individuals in that photo are. The latter was chosen, because it adds more weight to hours when more vultures were registered.

Apart from the vulture presence, the presence of other species - raven (Corvus corax Linnaeus, 1758), fox (Vulpes vulpes (Linnaeus, 1758)), stray domestic cat (Felis catus Linnaeus, 1758) and dog (Canis lupus familiaris Linnaeus, 1758) as well as humans - was recorded and analysed to account for the intra- and inter-species interactions and their effects on the vultures' visitation on the feeding site.

\section{Results and Discussion}

\section{Analyses of the independent events}

The data about the registered independent events are presented in Table 2. The feeding events are independent events containing photos of feeding vultures $(\min =1$ and $\max =30$ recorded griffon vultures per picture for the preincubation period, $\min =1$ and $\max =27$ for the incubation period). The independent events with marked vultures are all independent events containing photos of marked individuals $(\mathrm{min}=1$ and $\max =20$ marked birds per picture for the preincubation period, $\min =1$ and $\max =19$ for the incubation period). 
Table 2. Number and DR of independent events, number and DR of feeding events, number and DR of independent events with the participation of marked vultures for the pre-incubation period, the incubation period and in total

\begin{tabular}{|l|c|c|c|c|c|c|}
\hline \multicolumn{1}{|c|}{ Period } & $\begin{array}{c}\text { No. of indepen- } \\
\text { dent events }\end{array}$ & $\begin{array}{c}\text { DR } \\
\text { Independent events } \\
\text { per day }\end{array}$ & $\begin{array}{c}\text { No. of feed- } \\
\text { ing events }\end{array}$ & $\begin{array}{c}\text { DR } \\
\text { Feeding events } \\
\text { per day }\end{array}$ & $\begin{array}{c}\text { No. of indepen- } \\
\text { dent events with } \\
\text { marked vultures }\end{array}$ & $\begin{array}{c}\text { DR } \\
\text { Registration of marked } \\
\text { vultures per day }\end{array}$ \\
\hline Pre-incubation & 241 & 13.39 & 100 & 9.33 & 20 & 1.11 \\
\hline Incubation & 725 & 14.8 & 140 & 4.61 & 46 & 0.94 \\
\hline Total & $\mathbf{9 6 6}$ & $\mathbf{1 4 . 4 2}$ & $\mathbf{2 4 0}$ & $\mathbf{5 . 8 8}$ & $\mathbf{6 6}$ & $\mathbf{0 . 9 9}$ \\
\hline
\end{tabular}

Note: No. - number, DR - detection rate.

The $\chi^{2}$ (chi-square) method was used for testing the difference between the numbers of the independent events, the numbers of the feeding events and the numbers of the independent events with marked vultures for the two periods. These were tested for a statistically significant difference using an expected ratio of 18:49 (according the length of the two periods). For the numbers of the independent events and the numbers of the independent events with marked vultures no statistically significant difference was found $\left(\chi_{1}^{2}=1.81, \chi_{3}^{2}=0.40\right.$, $\mathrm{p}>0.05$ for both, $d f=1)$. For the numbers of the feeding events a statistically significant difference was found $\left(\chi_{2}^{2}=26.76, \mathrm{p}<<0.05, d f=1\right)$. This shows that the frequency of marked vultures using the feeding station remains similar for the two periods $\left(\mathrm{DR}_{\mathrm{pre}}=1.11, \mathrm{DR}_{\mathrm{inc}}=0.94\right)$, while the frequency of the feeding events lowers significantly after the beginning of the incubation $\left(\mathrm{DR}_{\mathrm{pre}}=9.33\right.$, $\left.\mathrm{DR}_{\text {inc }}=4.64\right)$. This disparity is a result of a difference between the numbers of the unmarked griffon vultures using the site in the two periods.

During this study 30 marked vultures were registered on the feeding station with a total of 66 feeding events $(D R=0.99)$ with their participation.

The feeding events for the incubation and the pre-incubation period for marked vultures (Fig. 2) do not show a statically significant difference. Comparison between the two samples with the MannWhitney U-test shows the same result $(U=395.50$, $p>0.05)$. The maximal number of feeding events with marked vultures per day for the pre-incubation period is 9 , and 6 for the incubation period.

A difference between the registered marked birds per photo during a feeding event was also observed (Fig. 3). A maximum of 20 marked vultures were observed during the pre-incubation, and up to 19 were observed during the incubation period. The sample range between the two periods is almost identical, but the mean for the first is $\overline{\mathrm{x}}_{\text {pre }}=2.59 \pm 0.09$ marked birds per picture, while for the second it is $\overline{\mathrm{X}}_{\text {inc }}=1.55 \pm 0.05$. When compared with the Mann-Whitney U-test the two samples have a statistically significant difference $(\mathrm{U}=6394349.50, \mathrm{p}<<0.05)$. It is probably due of the breeding behaviour of the griffon vulture: during the incubation the male and female individuals alternate incubating the egg, with the change happening every $37.4 \pm 0.5$ hours (Xirouchakis \& Mylonas, 2007), which means that at any given moment only one of the two birds can be feeding/ present at the station.

The length of the feeding events (Fig. 4) also differs for the two periods. The shortest registered feeding event during the pre-incubation is $\min _{\text {pre }}=0.11$ minutes, while for the incubation it is $\min _{\text {inc }}=0.10$. The longest are $\max _{\text {pre }}=61.15$ and $\max _{\text {inc }}=85.17$ minutes respectively, and the means are $\overline{\mathrm{x}}_{\text {pre }}=10.51 \pm 1.73$ and $\overline{\mathrm{x}}_{\text {inc }}=19.08 \pm$ 2.35 minutes. The Mann-Whitney U-test shows that there is a statistically significant difference in the distribution between the two samples $(\mathrm{U}=2036.50, \mathrm{p}<0.05)$.

These results show that the duration of the feeding events gets longer during the incubation period. This change combined with the lower number of those independent events during the second sample period can be explained with the fewer disturbance factors after the first egg was laid.

\section{Disturbance factors}

At the feeding stations many terrestrial predators have been observed like wolves $(\mathrm{Ca}$ nis lupus Linnaeus, 1758), dogs, jackals ( $\mathrm{Ca}$ nis aureus Linnaeus, 1758), cats, red foxes, etc. During the researched period of our study only feral dogs, domestic cats and foxes were registered. No grey wolves were recorded, and it is not clear whether they are a disturbance for the griffon vultures' presence, or whether they are actually benefiting from the scavenger populations (Stoynov et al., 2015). 


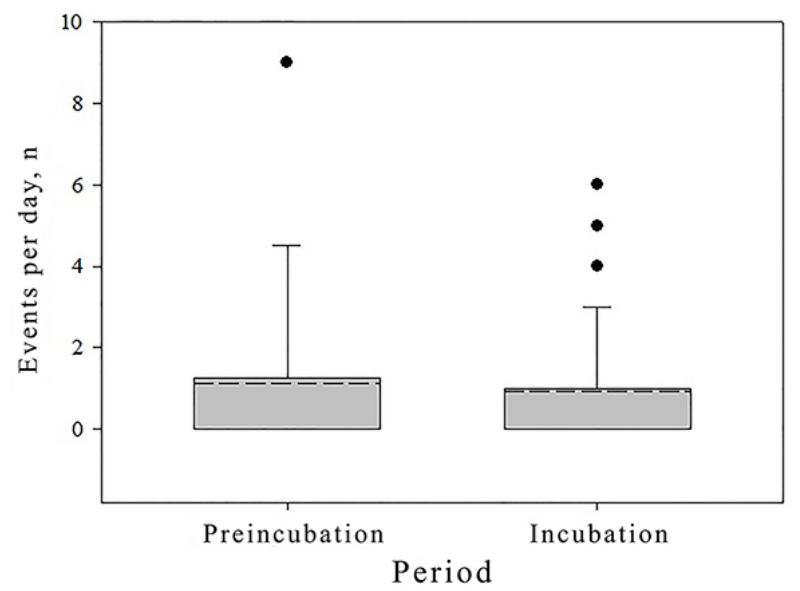

Fig. 2. Frequency of the feeding events during the pre-incubation and incubation periods for marked vultures. The lower line of the box shows the $10^{\text {th }}$ and the $25^{\text {th }}$ percentile, and the median ( $\mathrm{M}=0.00$ for both periods). The upper line of the box shows the $75^{\text {th }}$ percentile. The whisker marks the $90^{\text {th }}$ percentile. With dotted line is represented the mean value $\left(\overline{\mathrm{x}}_{\mathrm{pre}}=1.11 \pm 0.54, \overline{\mathrm{x}}_{\mathrm{inc}}=0.94 \pm 0.20\right)$.

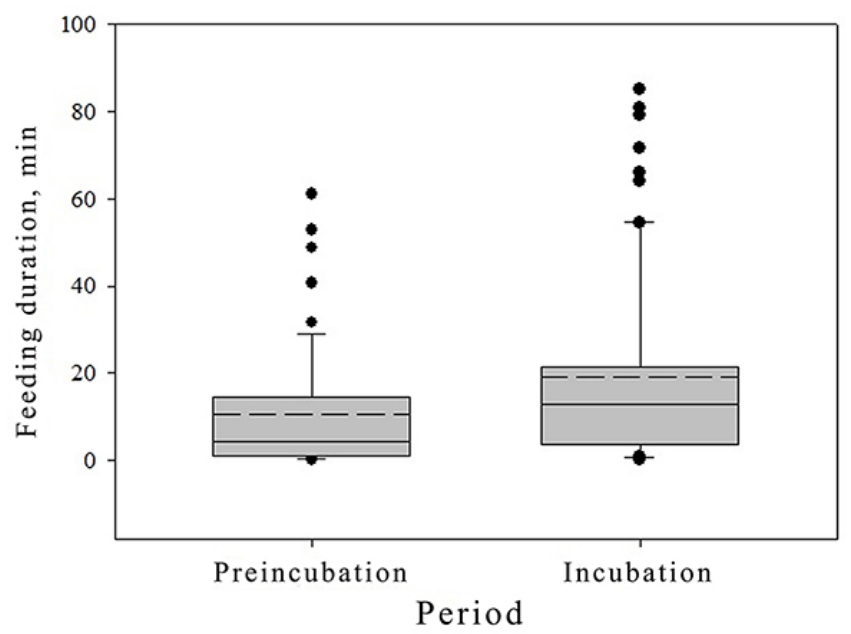

Fig. 4. Duration of the feeding events during the pre-incubation and incubation periods. The lower line of the box shows the $25^{\text {th }}$ percentile. The line inside the box represents the median $\left(\mathrm{M}_{\mathrm{pre}}=4.40, \mathrm{M}_{\mathrm{inc}}=12.90\right)$. The upper line of the box shows the $75^{\text {th }}$ percentile. The whiskers mark the $10^{\text {th }}$ and $90^{\text {th }}$ percentiles. With dotted line is represented the mean value $\left(\overline{\mathrm{x}}_{\text {pre }}=10.51 \pm 1.73, \overline{\mathrm{x}}_{\mathrm{inc}}=19.08 \pm 2.35\right)$.

The terrestrial predators visit the feeding site both during the day and the night, while the vultures are typical diurnal visitors. The overlap of the activity on the feeding station of the two groups (vultures and terrestrial predators) is $\Delta_{4}=0.54$ (Fig. 5). For the griffon vultures there are four peaks in the activity (two bigger at 10:55 and 14:27 and two smaller at 9:00 and 16:15) within the whole research period, while for the carnivores the visiting activity is more fluent and smoother with two peaks during the day. The biggest peak for the scavengers coincides with the biggest for the terres-

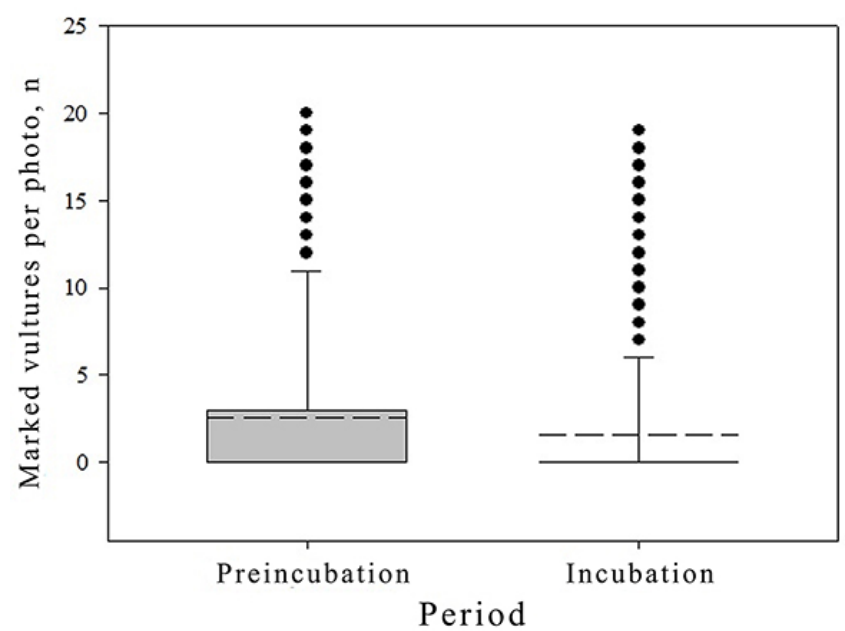

Fig. 3. Number of registered vultures per photo during the pre-incubation and incubation periods. The lower line of the box shows the $10^{\text {th }}$ and the $25^{\text {th }}$ percentile, and the median ( $\mathrm{M}=0.00$ for both periods). The upper line of the box shows the $75^{\text {th }}$ percentile. The whisker marks the $90^{\text {th }}$ percentile. With dotted line is represented the mean value $\left(\overline{\mathrm{x}}_{\mathrm{pre}}=2.59 \pm\right.$ $\left.0.09, \overline{\mathrm{x}}_{\mathrm{inc}}=1.55 \pm 0.05\right)$.

trial predators (at 10:55). After that there is a significant decline in the activity of the vultures on the site, most probably because of different disturbance factors.

Another disturbance factor is the presence of humans at the site for carcass depositing or other purposes. For the two periods 33 visits of people were registered via the camera trap ( 5 for the preincubation period and 28 for the incubation). The overlap between their and the vultures' activity patterns is $\Delta_{4}=0.61$. Alike the overlap of the terrestrial predators, a high peak was registered at 10:55, which overlaps with the target species' highest peak (Fig. 6). This probably is one of the reasons of the fast activity decline of the scavengers.

The most common species on the station is the raven, which was registered in a total of 7564 photos and in 803 independent events (189 during the preincubation and 614 during the incubation period). The raven is a constant visitor, and the activity overlap inside the species between the two periods is $\Delta_{4}=0.83$ (Fig. 7). The maximal number of individuals registered on a single photo for both periods is by the end of the active hours (14:23 and 15:21 for the pre-incubation period and 16:46 for the incubation period). The wider observed active period at the vulture restaurant during the incubation is due to the longer days.

The high density of the common raven visits of the feeding station means that the ravens and the griffon vulture are food resource competitors. For both of the periods the overlap of their activity is $\Delta_{4}=0.73$ (Fig. 8), which furthermore proves that they compete for the resources at the site. 


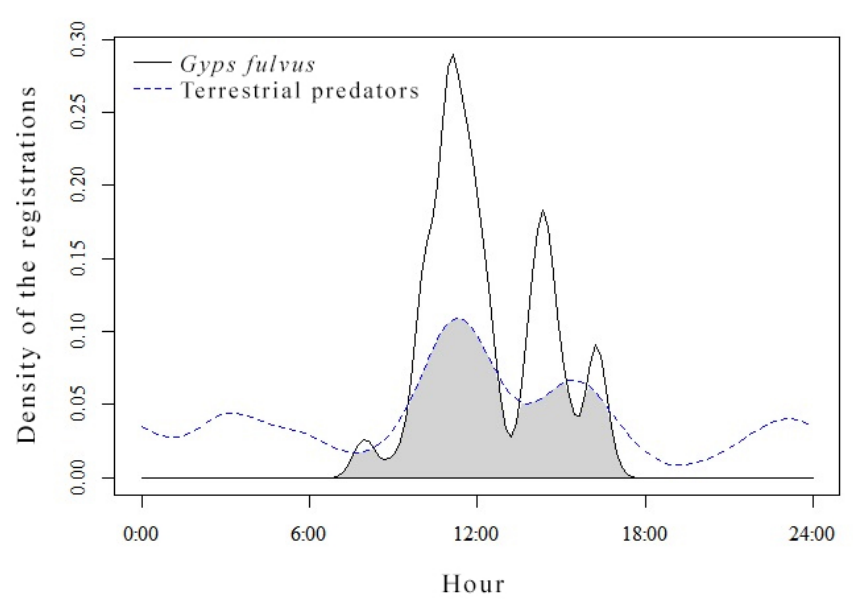

Fig. 5. Activity overlap between griffon vultures (black line) and terrestrial predators (dotted blue line) visiting the feeding station. The overlap coefficient is of $\Delta 4=0.54$.

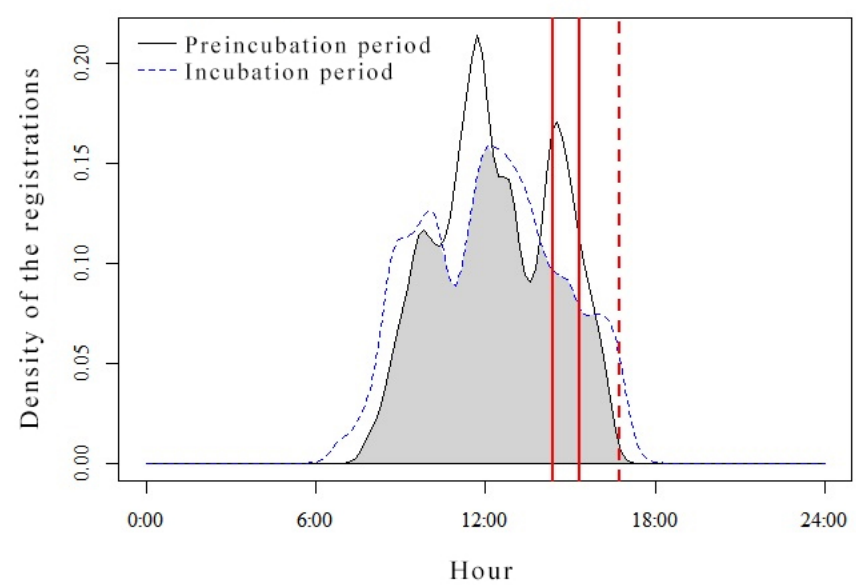

Fig. 7. Activity overlap between the ravens visiting the feeding station during the pre-incubation period (black line) and the incubation period (dotted blue line). The overlap coefficient is of $\Delta_{4}=0.83$. The red lines represent the hours in which the highest number of ravens were registered during the first period $(n=38)$. The red dotted line represents the hour in which the highest number of ravens were registered during the second period $(\mathrm{n}=50)$.

During the first period both species have common peaks (11:55 and 14:13) in the density of the registrations, but the ravens feed there in a longer time period. During the incubation the peaks are displaced and the highest points in the activity no longer overlap, but the ravens no longer use the station in a prolonged period. This displacement and the fact that overlap of the activity remains the same is probably an adaptive mechanism for the two species to use the resources better during the extremely important breeding and incubation period the egg laying for the griffon vulture is during December - February (Xirouchakis \& Mylonas, 2007), while for the raven it is February - March (Holyoak, 1967).

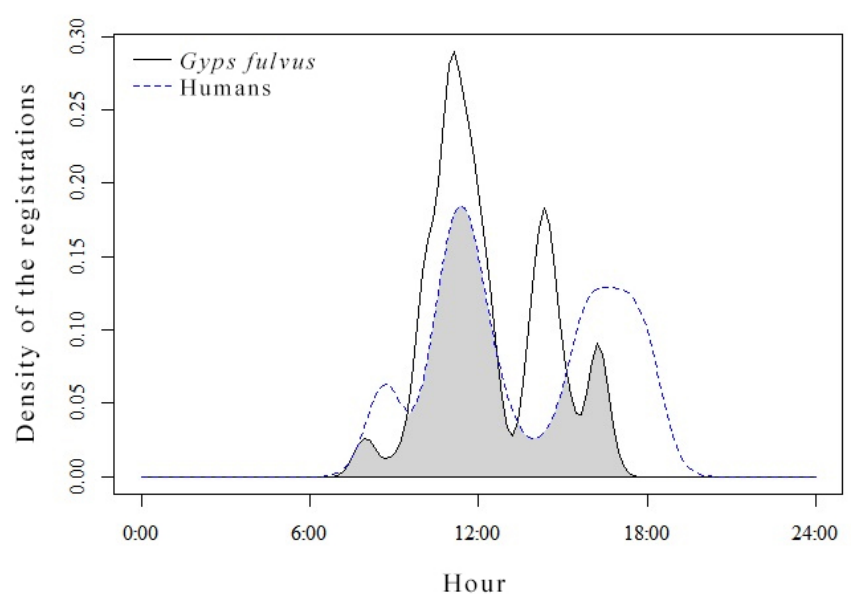

Fig. 6. Activity overlap between griffon vultures (black line) and humans (dotted blue line) visiting the feeding station. The overlap coefficient is of $\Delta_{4}=0.61$.

Comparison of the activity between successful and unsuccessful pairs

The overlap between the pre-incubation and incubation activity of the griffon vultures is $\Delta_{4}=0.73$, alike the ravens' (Fig. 9). For the first period only two peaks with high density of visiting the feeding station were observed, while for the second there are three main peaks and a secondary one. The two intervals with the highest density for each sample overlap. Like the ravens, the highest number of registered individuals in a single photo is during the second half of the daytime presence at the restaurant, and is displaced to a later hour during the incubation period.

For the first period, five male individuals (from the pairs) and four females were observed altogether in a single photo. For the males (Fig. 10) a decline was observed after entering the incubation period $\left(\overline{\mathrm{x}}_{\widehat{\gamma} \text { pre }}=1.82 \pm 0.05, \overline{\mathrm{x}}_{\text {केinc }}=1.40 \pm 0.04\right)$, and similar results were obtained for the females $\left(\overline{\mathrm{x}}_{\text {Opre }}=1.51 \pm 0.04, \overline{\mathrm{x}}_{\text {} \text { inc }}=0.81 \pm 0.03\right)$. The MannWhitney U-test for the males $(\mathrm{U}=584213.000$, $\mathrm{p}$ $<<0.05)$ and the females $(U=471620.50, p<<$ $0.05)$ proves a statistically significant difference between the incubation and pre-incubation periods.

For a stable griffon vulture population (both natural and reintroduced) the proportion between the two genders has to be 1:1 (Bosé et al., 2007). For the known pairs six permanent pairs with marked birds and two with unmarked wild females were observed. The males with wild females were not observed nesting, so they are considered not to be permanent in the area. Therefore, an offset ratio between the genders can be seen (Fig. 10). This suggests that the reintroduced colony in Kresna Gorge will not be stable enough until the young individuals are old enough to equalize the ratio. 

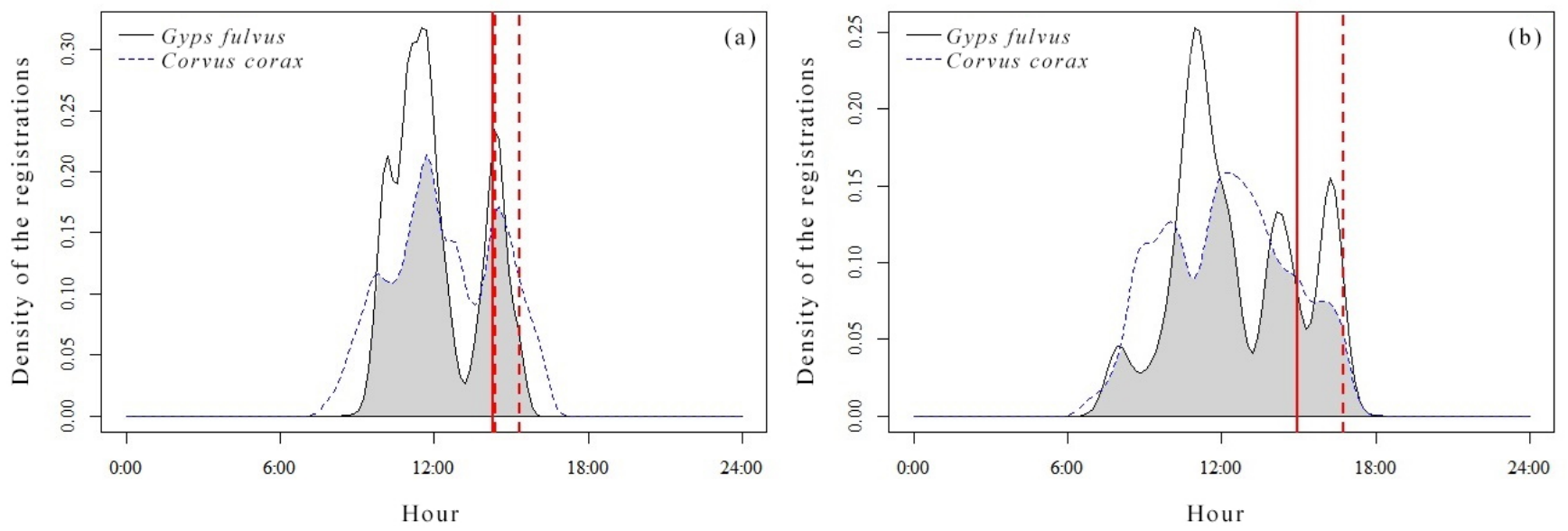

Fig. 8. Activity overlap between griffon vultures (black line) and ravens (dotted blue line) visiting the feeding station during: (a) the pre-incubation period. The overlap coefficient is of $\Delta 4=0.73$. The red line represents the hours in which the highest number of vultures were registered $(n=30)$. The red dotted lines represent the hours in which the highest number of ravens were registered $(n=38)$. (b) The incubation period. The overlap coefficient is of $\Delta 4=0.73$. The red line represents the hours in which the highest number of vultures were registered $(n=27)$. The red dotted line represents the hour in which the highest number of ravens were registered $(n=50)$.

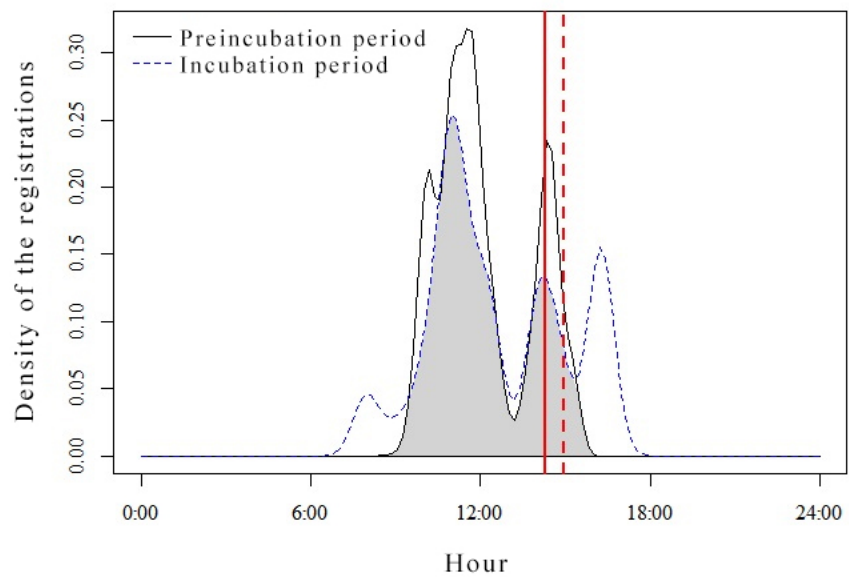

Fig. 9. Activity overlap between the griffon vultures visiting the feeding station during the pre-incubation period (black line) and the incubation period (dotted blue line) visiting the feeding station. The overlap coefficient is of $\Delta_{4}=0.73$. The red line represents the hour in which the highest number of vultures were registered during the first period $(n=30)$. The red dotted line represents the hour in which the highest number of vultures were registered during the second period $(n=27)$.

The nesting pairs, taking part in the incubation of the eggs, take turns at the nest, which happens once in every $37.4 \pm 0.5$ hours. As a result, the activity patterns between successfully and unsuccessfully nesting pairs is significantly different (Fig. 11).

For the successfully nesting pairs the activity overlap at the feeding site drastically lowers after entering the incubation period (from $\Delta_{4}=0.70$ and $\Delta_{4}=0.68$ to $\Delta_{1}=0.18$ and $\Delta_{1}=0.20$ ). The females visit the vulture restaurant in shorter time diapasons, but with a higher visitation density (they feed intensively without leaving the station / returning during the same feeding event). As for the males their intervals are much

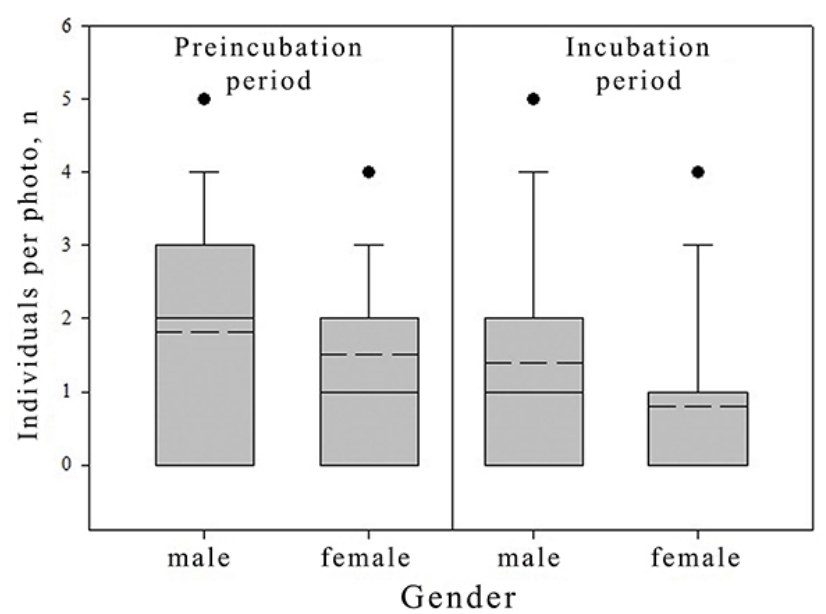

Fig. 10. Number of male and female individuals per picture during the pre-incubation and incubation periods. The lower line of the box shows the $10^{\text {th }}$ and $25^{\text {th }}$ percentile. The line inside the box represents the median $\left(\mathrm{M}_{\text {pre }}=2.00, \mathrm{M}_{\text {opre }}=1.00\right.$, $\mathrm{M}_{\text {inc }}=1.00 \mathrm{M}_{\text {inc }}=0.00$ ). The upper line of the box shows the $75^{\text {th }}$ percentile. The whisker marks the $90^{\text {th }}$ percentiles. With dotted line is represented the mean value $\left(\overline{\mathrm{x}}_{\mathrm{pre}}=1.82 \pm 0.05\right.$, $\left.\overline{\mathrm{x}}_{\text {कpre }}=1.51 \pm 0.04, \overline{\mathrm{x}}_{\text {○inc }}=1.40 \pm 0.04, \overline{\mathrm{x}}_{\text {कinc }}=0.81 \pm 0.03\right)$.

more spread, the visitation density lowers and the high peaks are almost entirely lost (and they feed in shorter intervals, often leaving and returning during the same feeding event). Also, during the incubation period the two individuals are never seen feeding together.

For the unsuccessfully nesting pairs the tendency is in an opposite direction - an increase of the overlap between the two individuals is observed (from $\Delta_{4}=0.81$ to $\Delta_{4}=0.92$ ). They are also seen feeding together in many occasions during both the pre-incubation and incubation period. And furthermore, the peaks stay the same for the two vultures and no displacement is seen. 

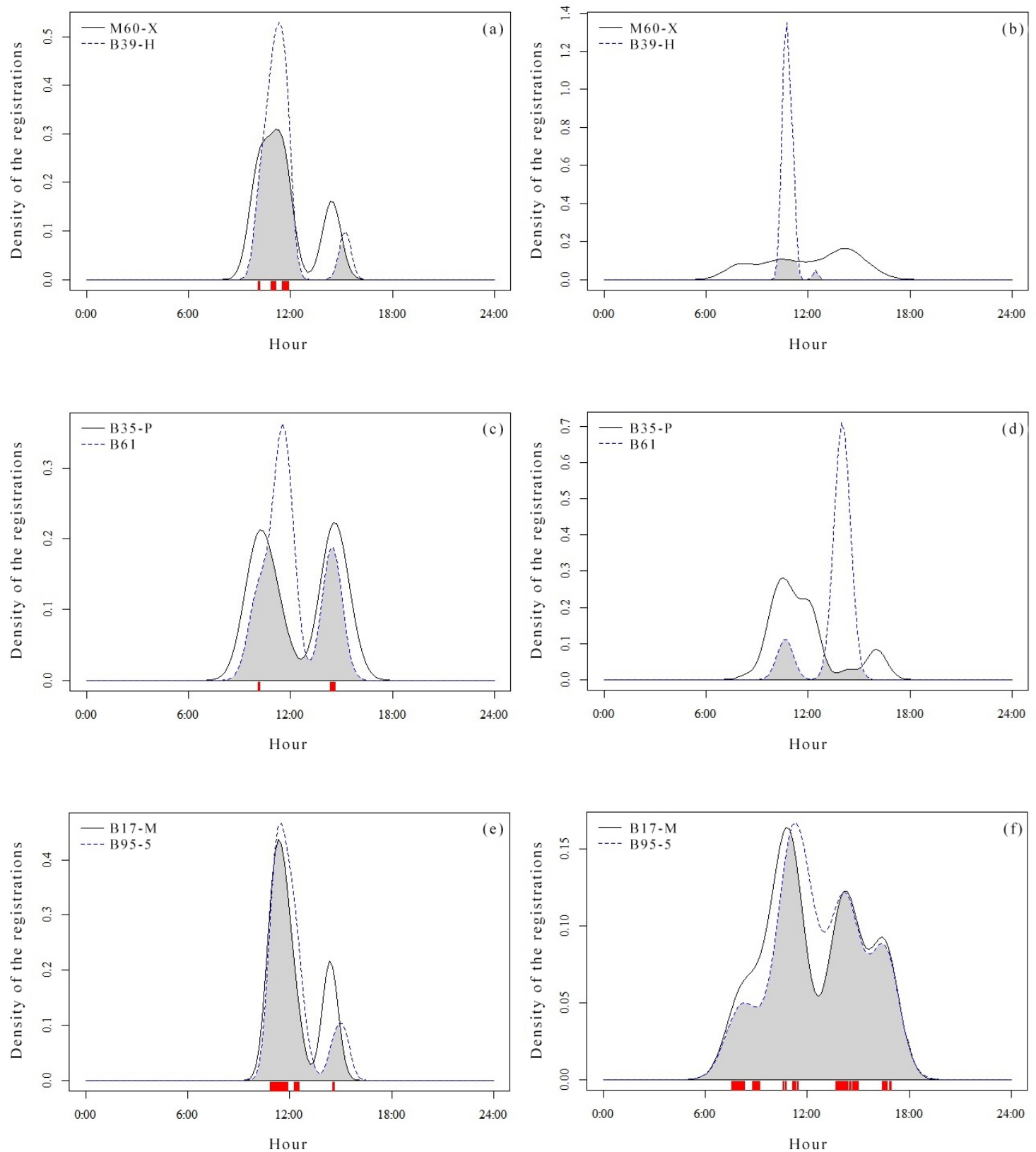

Fig. 11. Activity overlap at the feeding station for: (a) The successfully nesting pair M60-X (black line) and B39-H (blue dotted line) during the pre-incubation period. The overlap coefficient is of $\Delta_{4}=0.70$. The red rug represents the hours in which the two birds were observed together. (b) The pair M60-X (black line) and B39-H (blue dotted line) during the incubation period. The overlap coefficient is of $\Delta_{4}=0.18$. (c) The successfully nesting pair B35-P (black line) and B61 (blue dotted line) during the pre-incubation period. The overlap coefficient is of $\Delta_{4}=0.68$. The red rug represents the hours in which the two birds were observed together. (d) The pair B35-P (black line) and B61 (blue dotted line) during the incubation period. The overlap coefficient is of $\Delta_{4}=0.20$. (e) The unsuccessfully nesting pair B17-M (black line) and B95-5 (blue dotted line) during the pre-incubation period. The overlap coefficient is of $\Delta_{4}=0.81$. The red rug represents the hours in which the two birds were observed together. (f) The pair B17-M (black line) and B95-5 (blue dotted line) during the incubation period. The overlap coefficient is of $\Delta_{4}=0.92$. The red rug represents the hours in which the two birds were observed together.

\section{Conclusions}

Camera trap methods can be a valuable asset for a better understanding of the breeding biology of griffon vultures, including the intra- and interspecies relations especially at the feeding stations where multiple interactions occur.

This study has found a statistically significant difference between the independent feeding events during the pre-incubation and incubation periods.
A statistically significant difference was also observed between the number of vultures per photo for the two sample periods, as a result of a different number of unmarked wild birds and different activity patterns of the nesting pairs.

In spite of the fact that the terrestrial predators are active mainly during the night, they have a disturbing impact on the vulture feeding. Another important disturbance of the vulture feeding is the presence of 
people. The raven as the most abundant species at the feeding site is a natural food competitor of the griffon vulture although the two species have adapted their behaviour to use the restaurant more efficiently and successfully during different biological periods.

There is a significant difference in the activity overlap between the individuals of the successfully nesting pairs after the beginning of the incubation period and of the unsuccessfully nesting pairs.

Camera traps can be further used in studies of the mating ecology for individual breeding pairs, when a direct observation on the nest is hard or impossible. This can be a cheap alternative of the time-consuming field observations.

\section{Acknowledgements}

The authors express their sincere gratitude to the Fund for Wild Flora and Fauna team for their hard work on the griffon vulture reintroduction project in Kresna Gorge. The authors also thank Dr. E. Popova for the contribution and assistance.

\section{References}

Bosé M., Le Gouar P., Arthur C., Lambourdière J., Choisy J. P., Henriquet S., Lecuyer P., Richard M., Tessier C., Sarrazin F. 2007. Does sex matter in reintroduction of griffon vultures Gyps fulvus? Oryx 41(4): 503-508. DOI: $10.1017 / \mathrm{S} 0030605307000312$

Demo C., Cansi E.R., Kosmann C., Pujol-luz, J.R. 2013. Vultures And Others Scavenger Vertebrates Associated With Man-Sized Pig Carcasses: A Perspective In Forensic Taphonomy. Zoologia 30(5): 574-576. DOI: 10.1590/S1984-46702013000500010

Green R.E., Donázar J.A., Sánchez-Zapata J.A., Margalida A. 2016. Potential threat to Eurasian griffon vultures in Spain from veterinary use of the drug diclofenac. Journal of Applied Ecology 53(4): 993-1003. DOI: 10.1111/1365-2664.12663

Green R.E., Newton I., Shultz S., Cunningham A.A., Gilbert M., Pain D.J., Prakash V. 2004. Diclofenac poisoning as a cause of vulture population declines across the Indian subcontinent. Journal of Applied Ecology 41(41): 793-800. DOI: 10.1111/j.0021-8901.2004.00954.x

Holyoak D. 1967. Breeding biology of the Corvidae. Bird Study 14(3): 153-168. DOI: 10.1080/00063656709476159

BirdLife International. 2017. Gyps fulvus (amended version of 2016 assessment). In: The IUCN Red List of Threatened Species 2017: e.T22695219A118593677. Retrieved on 14.03.2018. DOI: 10.2305/IUCN.UK.20173.RLTS.T22695219A118593677.en

Kane A., Wolter K., Neser W., Kotze A., Naidoo V., Monadjem A. 2016. Home range and habitat selection of Cape Vultures Gyps coprotheres in relation to supplementary feeding. Bird Study 63(3): 387-394. DOI: 10.1080/00063657.2016.1214105

Margalida A., Campión D., Donázar J.A. 2011. Scavenger turned predator: European vultures' altered behaviour. Nature 480(7378): 457. DOI: 10.1038/480457b
Margalida A., Colomer M.A.À. 2012. Modelling the effects of sanitary policies on European vulture conservation. Scientific Reports 2(753): 1-7. DOI: 10.1038/srep00753

Margalida A., Donaar J., Carrete M., Sachez-Zapata J. 2010. Sanitary versus environmental policies: fitting together two pieces of the puzzle of European vulture conservation. Journal of Applied Ecology 47: 931-935. DOI: 10.1111/j.1365-2664.2010.01835.x.

Margalida A., Pérez-García J.M., Moreno-Opo R. 2017. European policies on livestock carcasses management did not modify the foraging behavior of a threatened vulture. Ecological Indicators 80: 66-73. DOI: 10.1016/j. ecolind.2017.04.048

Meredith M., Ridout M. 2017. Overlap: Estimates of Coefficient of Overlapping for Animal Activity Patterns. Available from: https://cran.r-project.org/package=overlap

O’Connell A.F., Nichols J.D., Karanth K.U. (Eds.). 2011. Camera Traps in Animal Ecology: Methods and Analyses. Springer Japan. 271 p. DOI: 10.1007/978-4-431-99495-4

Peshev H., Stoynov E., Grozdanov A., Vangelova N. 2016. Re-introduction of Griffon Vulture Gyps fulvus in Kresna Gorge of Struma River, Bulgaria. Annual Report 2015. Available from: http://fwff.org/docs/KresnaGorge-Griffon-Vulture-re-introduction-2015.pdf

Peshev H., Stoynov E., Vangelova N., Grozdanov A. 2017. Re-introduction of Griffon Vulture Gyps fulvus in Kresna Gorge of Struma River, Bulgaria. Annual Report 2016. DOI: 10.1017/CBO9781107415324.004

QGIS Development Team. 2017. QGIS Geographic Information System, 2.18.10. Available from: http://qgis.osgeo.org.

R Core Team. 2017. R: A Language and Environment for Statistical Computing. Vienna, Austria. Available from: https://www.r-project.org

Ridout M.S., Linkie M. 2009. Estimating overlap of daily activity patterns from camera trap data. Journal of $\mathrm{Ag}$ ricultural, Biological, and Environmental Statistics 14(3): 322-337. DOI: 10.1198/jabes.2009.08038

Samson A., Ramakrishnan B. 2017. Scavenging Mode of Vertebrate Scavengers on Domestic Buffalos Bubalus bubalis (Linnaeus, 1785) Killed by Tiger Panthera tigris and Natural Deaths in Southern India. Podoces 12(1): 22-26.

Sarrazin F., Bagnolini C., Pinna J.L., Danchin E. 1994. Breeding biology during establishment of a reintroduced Griffon Vulture Gyps fulvus population. Ibis 138(2): 315-325. DOI: 10.1111/j.1474-919X.1996.tb04344.x

Schmid F., Schmidt A. 2006. Nonparametric estimation of the coefficient of overlapping - theory and empirical application. Computational Statistics \& Data Analysis 50: 1583-1596. DOI: 10.1016/j.csda.2005.01.014

Stoynov E., Grozdanov A. 2011. First Breeding of Griffon Vulture (Gyps Fulvus) During the Reintroduction Activities in Kresna Gorge. In: Youth Scientific Conference 'Kliment's Days'(Sofia, Bulgaria, November 2011). Sofia. P. 104-106. DOI: 10.13140/RG.2.1.2714.5684

Stoynov E., Peshev H. 2012. Re-introduction of Griffon Vulture Gyps fulvus in Kresna Gorge of Struma River, Bulgaria. Annual Report 2011. Blagoevgrad: Fund for Wild Flora and Fauna.

Stoynov E., Peshev H. 2013. Re-introduction of Griffon Vulture (Gyps fulvus) in Kresna Gorge of Struma River, 
Bulgaria. Annual Report 2012. Blagoevgrad: Fund for Wild Flora and Fauna. 14 p.

Stoynov E., Peshev H. 2014. Re-introduction of Griffon Vulture Gyps fulvus in Kresna Gorge of Struma River, Bulgaria. Annual Report 2013. Blagoevgrad: Fund for Wild Flora and Fauna.

Stoynov E., Peshev H. 2015. Re-introduction of Griffon Vulture Gyps fulvus in Kresna Gorge of Struma River, Bulgaria. Annual Report 2014. Blagoevgrad: Fund for Wild Flora and Fauna.

Stoynov E., Peshev H., Grozdanov A., Delov V., Vangelova N., Peshev D. 2014. New data for the presence and numbers of some conservation dependent birds in Kresna gorge with proposal of original method for individual identification of vultures. In: First National Conference of Biotechnology (Sofia, 2014). Sofia. P. 320-331.

Stoynov E., Vangelova N., Zlatanova D., Peshev H., Grozdanov A., Parvanov D., Delov V. 2015. Is the Wolf Presence Beneficial to Vultures in Europe? Available from: https://www.researchgate.net/publication/281118556 Is_the_Wolf_presence_beneficial_for_vultures_in_Europe. DOI: $10.13140 /$ RG. $^{-} \cdot 1.2184 .3685$

Systat Software. 2007. SigmaStat. 3.5. Available from: http:// grass.osgeo.org

Systat Software. 2008. SigmaPlot. 11.0. Available from: www.systatsoftware.com

Tobler M. 2015. Camera Base 1.7. Atrium. Available from http://www.atrium-biodiversity.org/tools/camerabase/
Wilson B. 2015. An introduction to camera trapping of wingtagged vultures in southern Africa. Vulture News 69: 3-22. DOI: 10.4314/vulnew.v69i1.1

Wolter K., Whittington-Jones C. 2011. Vulture Restaurant Monitoring Protocol. Available from: http://www.vulpro.com/wp-content/uploads/2016/08/Wolter-VultureRetaurant-Monitoring-Protocol-VulPro-2011.pdf

Xirouchakis S.M., Andreou G. 2009. Foraging behaviour and flight characteristics of Eurasian griffons Gyps fulvus in the island of Crete, Greece. Wildlife Biology 15: 37-52. DOI: 10.2981/07-090

Xirouchakis S.M., Mylonas M. 2005. Status and structure of the griffon vulture (Gyps fulvus) population in Crete. European Journal of Wildlife Research 51(4): 223-231. DOI: 10.1007/s10344-005-0101-4

Xirouchakis S.M., Mylonas M. 2007. Breeding behaviour and parental care in the Griffon Vulture Gyps fulvus on the island of Crete (Greece). Ethology Ecology \& Evolution 19(1): 1-26. DOI: 10.1080/08927014.2007.9522578

Zlatanova D., Racheva V., Peshev D., Gavrilov G. 2009. First Hard Evidence of Lynx (Lynx Lynx L.) Presence in Bulgaria. Biotechnology \& Biotechnological Equipment 23(sup.): 184-187. DOI: 10.1080/13102818.2009.10818396

Zuberogoitia I., Martínez J. E., Margalida A., Gómez I., Azkona A., Martínez J. A. 2010. Reduced food availability induces behavioural changes in Griffon Vulture Gyps fulvus. Ornis Fennica 87(2): 52-60.

\title{
ИСПОЛЬЗОВАНИЕ КОРМОВЫХ МЕСТ БЕЛОГОЛОВЫМ СИПОМ (GYPS FULVUS) В БОЛГАРИИ, ВЫЯВЛЕННОЕ С ПОМОЩЬЮ ФОТОЛОВУШЕК
}

\author{
Д. И. Ненов ${ }^{1, *}$, Д. П. Златанова ${ }^{1}$, Э. Х. Стойнов ${ }^{2, * *}$, Х. В. Пешев ${ }^{2}$, А. П. Грозданов ${ }^{1}$ \\ ${ }^{1}$ Софийский университет имени святого Климента Охридского, Болгария \\ *e-mail:dinenov@uni-sofia.bg \\ ${ }^{2}$ Фонд дикой флоры и фауны, Болгария \\ **e-mail:pirin@fwff.org
}

\begin{abstract}
Была изучена группа белоголовых сипов в Кресна Горге во время посещения ими кормовой станции рядом с деревней Ракитна после реинтродукции в этом местообитании. Для лучшего понимания репродуктивного поведения белоголового сипа, включая внутри- и межвидовые отношения, был использован метод фотоловушек. Было обнаружено статистически значимое различие между независимыми случаями кормления во время прединкубационного и инкубационного периодов развития сипа. Продолжительность кормления также различается. Так, продолжительность второго периода больше. Кроме того, наблюдалось статистически значимое различие между количеством особей на фотографию в течение двух периодов выборки в результате различного количества немаркированных птиц и различных форм активности гнездящихся пар. Несмотря на то, что наземные хищники также активны в течение ночи, их дневное присутствие приводит к достаточно высокому перекрытию между двумя экологическими группами, что свидетельствует о том, что плотоядные животные являются фактором беспокойства для падальщиков. Ворон является наиболее распространенным видом в местах кормления и, таким образом, является конкурентом в отношении белоголового сипа. Эти два вида адаптировали свое поведение для более успешного использования мест кормления в течение различных биологических периодов. Значительное снижение перекрытия активности особей успешно гнездящихся пар наблюдалось на станции питания после начала инкубационного периода. С другой стороны, перекрытие активности неудачно гнездившихся пар увеличилось во второй период выборки. Фотоловушки могут использоваться при дальнейших исследованиях гнездовой экологии для отдельных пар особей, когда прямое наблюдение за гнездованием является затруднительным или невозможным. Это может быть дешевой альтернативой трудоемким полевым наблюдениям.
\end{abstract}

Ключевые слова: белоголовый сип, гнездящиеся и не гнездящиеся пары, фотоловушка 